\title{
Optimization of Syr Darya Water and Energy Uses
}

\author{
Elena Antipova and Alexi Zyryanov, JSC Kyrgyzenergo, Bishek, Kyrgyz Republic, \\ Daene McKinney, Member IWRA, The University of Texas, Austin, Texas, USA, and \\ Andre Savitsky, Ecological Center, Tashkent, Uzbekistan
}

\begin{abstract}
Since independence, joint use of water resources in the Aral Sea basin has been a critical international problem between the Central Asian republics, especially in the Syr Darya basin where the tradeoffs between use of water for agricultural and energy production are very acute. Previous centralized methods of planning, formation of independent countries, and the emergence of national interests have made the coordinated operation of the Naryn-Syr Darya Cascade of reservoirs complicated. In order to implement recent international agreements on the use of water and energy resources of the Syr Darya basin and provide the upstream-downstream exchanges of electric fuel and energy resources required by the agreements, a model was developed to optimize operation modes for the major reservoirs of the basin. This model was used as the basis for developing a complex model of the operation of the Naryn Cascade of hydropower plants and the interactions of the Kyrgyz Republic energy system and the other Syr Darya basin countries through the Central Asian electricity pool. The model is described and the results of using the model to analyze three scenarios of Nayrn Cascade operation are presented.
\end{abstract}

Keywords: Aral Sea, international water resources management, optimization model.

\section{Introduction}

Joint use of water resources in the Aral Sea basin is one of the key international problems among the Central Asian countries of Kazakhstan, Kyrgyzstan, Tajikistan, Turkmenistan, and Uzbekistan. This problem is especially acute in the Syr Darya basin (Figure 1), where 93 percent of the mean annual flow is regulated by storage reservoirs, and all water resources are utilized. The major water consumer in the basin is irrigated agriculture, and major nonconsumptive water users include hydroelectric power plants (HPPs). Previously, within the USSR, regulation of water use for irrigation and electric power generation was centralized; formation of independent countries in Central Asia made these issues more complicated. National interests joined the already arisen regional crisis of the Aral Sea. Consequently, these problems have disrupted the coordinated operation of the Naryn-Syr Darya Cascade of reservoirs from the previous single schedule and primary orientation of water supply to irrigated areas of the basin.

Under these circumstances, the need for a new agreement on a higher level became apparent. Such an agreement was developed under the aegis of the Executive Committee (EC) of the Central Asian Economic Community (CAEC). On March 17, 1998, Prime Ministers of the Republic of Kazakhstan, the Kyrgyz Republic, and the Republic of Uzbekistan signed the agreement on the use of water and energy resources of the Syr Darya basin between governments of these countries. Later, in 1999, the Republic of Tajikistan joined this agreement.

This agreement provides for the exchange of electric power and fuels to settle water and energy relations between the basin countries. The agreement also defines areas of future joint activities concerning rational use of water, fuel, and energy resources in the region. Concurrent with the Syr Darya agreement, the countries signed an agreement on the parallel operation of the energy systems of Central Asia, the agreement on cooperation in the area of environment and rational nature use, and other interstate acts. These agreements complement each other and open up opportunities for closer cooperation.

It became apparent that the Syr Darya water and energy agreement, being a framework agreement, required implementation mechanisms. Meetings of the Water and Energy Uses Round Table under the EC CAEC address these issues. At these meetings heads of water and energy sectors and representatives of governmental agencies of the countries participating in the agreement take part. In past meetings, participants noted the importance of developing a model to optimize operation modes for the major reservoirs of the Syr Darya basin that form the Naryn-Syr Darya Cascade. The Round Table (with financial and technical assistance from USAID) initiated development of a model to optimize operation modes of major reservoirs of the Naryn-Syr Darya Cascade with the help of a group of specialists from the water and energy sectors of their countries and organizations. Three 


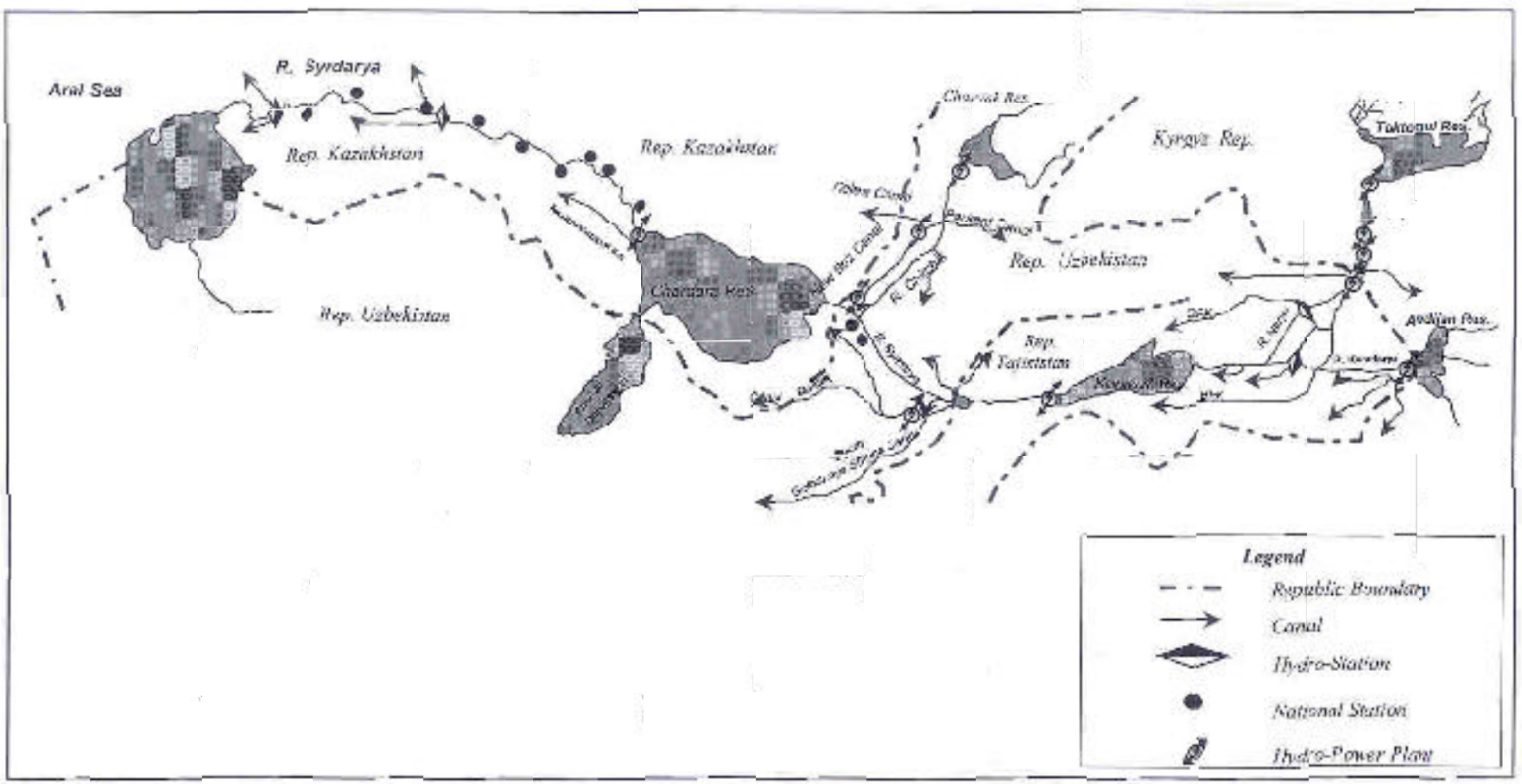

Figure 1. Scheme of the Syr Darya Basin. Source (WARMAP Project).

component models (river, energy, and planning zone) were prepared in the General Algebraic Modeling System (GAMS) programming language (Brooke et al., 1998) as stand-alone components.

To achieve tighter integration of the water and energy model components, the river component was used as a base for developing a complex energy model for the Naryn Cascade of HPPs, including the interactions of the Kyrgyz Republic and the other Syr Darya basin countries through water supplies and mutual fuel (energy carrier) deliveries. Since their independence the five Central Asian republics (Kazakhstan, Kyrgyzstan, Tajikistan, Turkmenistan, and Uzbekistan) have been striving to find ways of allocating and sharing the integrated water and energy systems developed under the Soviet Union. In this region, it is necessary to balance the solution of these resource management problems across several nations and several river basins. The work reported here is the first phase of a larger work involving the solution of the water and energy resources use problem for both the Syr Darya and Amu Darya river basins and the combined energy systems of all five Central Asian countries.

\section{Water and Energy Facilities of the Syr Darya Basin}

Construction of Toktogul reservoir in the Syr Darya basin was called for by the agricultural production targets set by the government of the former Soviet Union. These targets were aimed at quickly raising cotton production in the country from 4.3 million tons in 1960 to 10 to 11 million tons in 1990. In implementing these targets, great impor- tance was placed on developing irrigation in the Syr Darya basin, the most important cotton farming region in Central Asia. It was anticipated that irrigated lands would be increased in the Syr-Darya basin from 2.1 million hectares in 1960 to 6.4 million hectares by 1990. However, as early as 1960 the total water diversion in the basin amounted to over $30 \mathrm{~km}^{3}$, exceeding the flow of the river in low water years. At that time, the capacity of the water infrastructure of the basin could not meet the demand for irrigation water in dry periods. In the middle course, the Kairakum reservoir depended on the natural river flow, since there were no multi-year storage reservoirs in the basin. At that time, there were three main flow control systems in the Syr Darya basin: Kairakum reservoir $\left(2.6 \mathrm{~km}^{3}\right.$ active storage capacity), and Farkhad and Kyzylorda Hydraulic Systems. Construction of the Chardara reservoir $\left(4.7 \mathrm{~km}^{3}\right.$ active storage) was near completion. More intensive was the construction of canals: the Big Fergana Canal, the North-Fergana Canal, secondary canals, and other facilities.

Because of poor coordination of the areas under development and low efficiency of the irrigation systems, the discrepancy between irrigation demand and water supply in almost all watercourses in the basin was very acute. In order to improve available water supply, construction of Charvak reservoir (1.2 $\mathrm{km}^{3}$ active capacity) started on the Chirchik river and the Kampuravatsky reservoir (1.6 $\mathrm{km}^{3}$ active capacity) on the Karadarya river. However, seasonal flow control of the Syr Darya river and its tributaries did not solve the problem of stable water supply because of significant discrepancies between anticipated and actual levels in low water years. Because of this, it 
was decided to implement multi-year storage by construction of Toktogul reservoir $\left(14 \mathrm{~km}^{3}\right.$ active capacity and 8.7 $\mathrm{km}^{3}$ firm yield) on the Naryn river with an operating regime determined by irrigation requirements. With the reservoir in place, the firm water resources in the middle and lower reaches of the Syr Darya river increased by 4.5 $\mathrm{km}^{3}$, or by more than by 30 percent.

The use of the reservoir for power generation was considered a side benefit. Since the impact of Toktogul reservoir on irrigation is limited to the Syr Darya basin and power generation affects the whole Central Asian region, a hydroelectric power plant (HPP) was constructed at Toktogul. Construction of the Toktogul HPP and $500 \mathrm{kV}$ high-voltage lines closed the main loop of the Central Asian Energy Pool (CAEP) and increased the reliability and quality of power supply to users in the region.

The initial design of Toktogul reservoir specified that, in accordance with the irrigation regime, the release from the reservoir in the non-vegetation season (October to March) should be limited to $180 \mathrm{~m}^{3} / \mathrm{sec}$ (about 400 million $\mathrm{m}^{3} /$ month), providing for minimum electricity generation. The irrigation release regime is very close to the natural one, enabling not only the preservation of the environment but also the creation of conditions for maintaining the required land reclamation conditions in the areas adjacent to the river.

Toktogul reservoir was commissioned in 1974, and for a long time it could not be filled to capacity. Its storage did not exceed 5 to $6 \mathrm{~km}^{3}$ and only with the beginning of high water years in August 1988 did the reservoir storage finally reach full capacity $\left(19.5 \mathrm{~km}^{3}\right)$. By 1990 , the system was managed according to the design requirements. By that time, irrigated areas in the Syr Darya basin had reached 3.30 million hectares.

\section{Water and Energy Complexes in the Syr Darya Basin}

Energy Complex of Kyrgyzstan and the Naryn River

The Kyrgyz energy system comprises 17 operating power plants with the total capacity of 3,586 MW including 15 HPPs (2,948 MW) and two thermal electric power plants (TPP) $(638 \mathrm{MW})$. In the areas of the republic within the Syr Darya basin, there are five large HPPs (Toktogul, Kurpsai, Tashkumyr, Shamaldysai, and Uch-Kurgan) located in a cascade in the lower reaches of the Naryn river. The total rated capacity of HPPs in the Naryn Cascade is 2,870 MW and average long-term output of electric power is 10,000 million $\mathrm{kWh} /$ year. Thermal power plants in Bishkek (588 MW) and Osh (50 MW) with total design output of 4,100 million $\mathrm{kWh} /$ year are run on natural gas, fuel oil and coal (Bishkek TPP). HPPs account for 82 percent of the rated capacity and more than 90 percent of the electric power generation. However, in the HPP balance over 97 percent of the capacity is concentrated in the Naryn Cascade controlled by Toktogul Reservoir. Other HPPs of the cascade have small storage capacity and provide daily control of discharges from upstream. Basic characteristics and parameters of the Naryn Cascade are given in Table 1.

\section{National and Regional Interests of the Syr Darya Riparian Nations in the Use of Water and Energy Resources of the Basin}

Before 1990, most of the power generated by the Naryn Cascade HPPs from the vegetation period (April to September) releases was transmitted to neighboring regions. Kyrgyzstan in the non-vegetation period (October to March) received electric power from the CAEP and natural gas, coal and fuel oil for TPPs from the other regions (now the independent Central Asian republics and Russia). Fuel consumption and electric power production by TPPs are summarized in Table 2 . The scheme existing at that time ensured efficient and integrated operation of the fuel-and-power sectors and water complexes of the region (see Figure 2, irrigation mode).

The situation changed drastically in 1991, when independent states were established in Central Asia. Because of complications in intergovernmental relations and account settlements, introduction of national currencies, growing prices of oil, coal, natural gas, and transportation, the supply of fuel and electricity to Kyrgyzstan from the other republics was reduced. This radically affected the structure of the Kyrgyz fuel-and-energy balance. Because of decreased production of fuel in Kyrgyzstan, the output and distribution of thermal power from TPPs in Kyrgyzstan fell two times and organic fuel consumption reduced, giving rise to increased electric power demand by the population for heating, hot water supply, and cooking. With these changes, the Kyrgyz electricity demand in the non-vegetation period increased from 50 percent of the annual amount in 1990-91 to 75 percent in 1996 to 1999 (Figure 3).

To provide for the electric power demand in Kyrgyzstan under these conditions, the Toktogul operation mode was switched from irrigation to power generation. Toktogul HPP

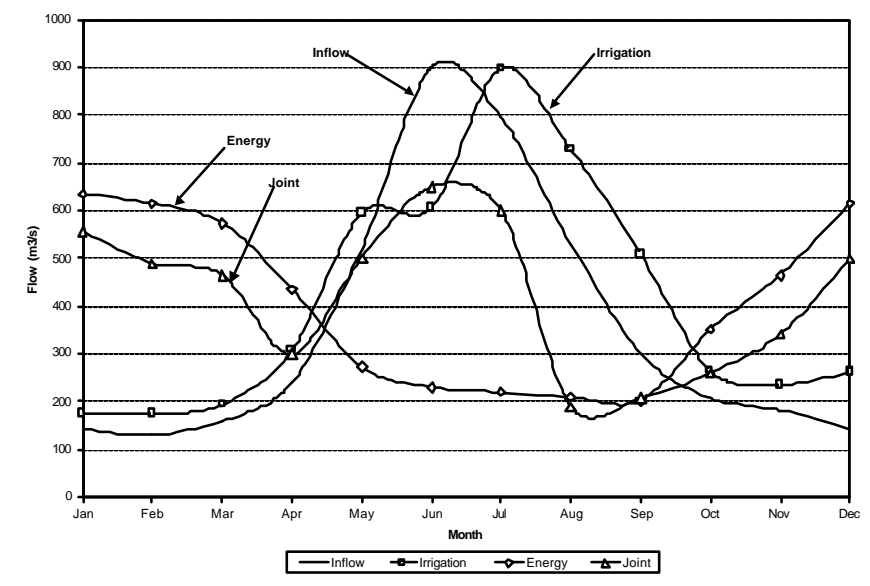

Figure 2. Toktogul reservoir operation under different regimes. 
Table 1. Basic Parameters of the Naryn Cascade

\begin{tabular}{|c|c|c|c|c|c|c|}
\hline \multirow[b]{2}{*}{ Item } & \multirow[b]{2}{*}{ Units } & \multicolumn{5}{|c|}{ Naryn Cascade HPPs } \\
\hline & & Toktogul & Kurpsai & Tashkumyr & Shamaldysai & Uch-Kurgan \\
\hline Rated capacity & MW & 1,200 & 800 & 450 & 240 & 180 \\
\hline $\begin{array}{l}\text { Annual long-term output } \\
\text { of electric power }\end{array}$ & $\mathrm{M} \mathrm{kWh}$ & 4,100 & 2,630 & 1,555 & 902 & 820 \\
\hline $\begin{array}{l}\text { Average long-term flow } \\
\text { Typical reservoir levels }\end{array}$ & $\mathrm{m}^{3} / \mathrm{sec}$ & 359 & 391 & 439 & 438 & 429 \\
\hline $0 \bullet$ Full storage (DFSL) & M & 900 & 724 & 628 & 572 & 539.5 \\
\hline b. Dead storage (DSL) & M & 837 & 721.6 & 626.5 & 569.9 & 536.5 \\
\hline \multicolumn{7}{|l|}{ Typical heads } \\
\hline $0 \bullet$. Maximum & M & 180 & 106 & 58.5 & 31 & 36 \\
\hline b. Minimum & M & 110 & 90.5 & 40 & 25.2 & 18.5 \\
\hline c. Estimated & M & 140 & 91.5 & 53 & 26 & 29 \\
\hline Reservoir area at DFSL & $\mathrm{km}^{2}$ & 284.3 & 12.0 & 7.8 & 2.4 & 4.0 \\
\hline Storage at DFSL & $\mathrm{Mm}^{3}$ & 19,500 & 370 & 140 & 39.4 & 52.5 \\
\hline Active storage capacity & - & 14,000 & 35 & 10 & 5.42 & 20.9 \\
\hline Type of control & & Long-period & Weekly & Weekly & Weekly & Daily \\
\hline Number of turbines & Pcs & 4 & 4 & 3 & 3 & 4 \\
\hline Design flow rate per turbine & $\mathrm{m}^{3} / \mathrm{sec}$. & 250 & 243 & 319 & 345 & 190 \\
\hline $\begin{array}{l}\text { Max. flow rate through } \\
\text { turbines }\end{array}$ & - & 960 & 972 & 957 & 1,035 & 760 \\
\hline Hydropower unit efficiency & $\%$ & 87 & 90 & 85 & 80 & 80 \\
\hline $\begin{array}{l}\text { Unit flow rate of water per } \\
1 \mathrm{kWh} \text { at } \mathrm{H}_{\text {estimated }}\end{array}$ & $\mathrm{m}^{3} / \mathrm{kWh}$ & 2.95 & 4.4 & 7.7 & 15.6 & 14.0 \\
\hline $\begin{array}{l}\text { Flow rate through water } \\
\text { passage structures at } \\
\text { DFSL, total: }\end{array}$ & $\mathrm{m}^{3} / \mathrm{sec}$ & 3,500 & 2,537 & 3,293 & 3,090 & 3,250 \\
\hline Bottom spillway & - & 2,340 & 1,037 & 2,093 & 3,090 & 2,296 \\
\hline Transfer spillway & - & 1,160 & 1,500 & 1,200 & - & 954 \\
\hline
\end{tabular}

Table 2. Fuel Consumption and Electric Power Production at Kyrgyz TPPs in 1988 to 1999

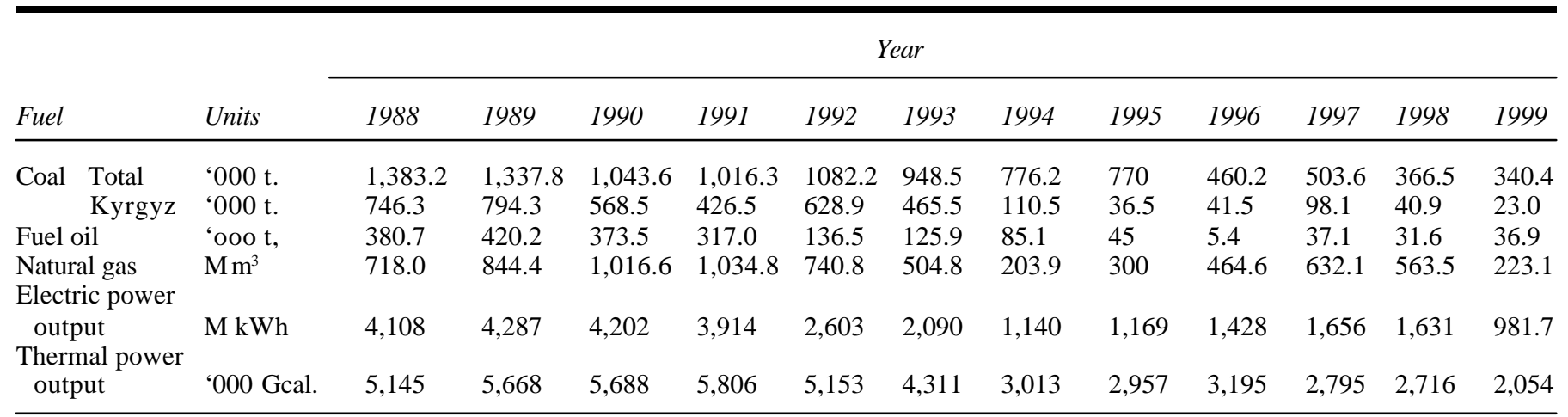

is the main power plant in the Naryn Cascade providing average long-term generation of electricity of 5,000 million $\mathrm{kWh}$ ( 45 percent of the Kyrgyz energy balance). The share of hydropower in the republic's electricity balance did not exceed 70 percent prior to 1990 . However, in subsequent years it rose to 91 percent and Toktogul releases for power generation in non-vegetation periods rose from $2.8 \mathrm{~km}^{3}$ to $8.5 \mathrm{~km}^{3}$ (Figure 4). Intensive use of water resources for power generation, along with changes in the Toktogul operating regime created serious problems in the Syr Darya basin in both summer and winter periods. The years 1991 to 1994 and 1999 were typical of deviations from the earlier pattern of Naryn river water management. In that period, the supply of electricity and fuel to Kyrgyzstan in the non-vegetation period from Kazakhstan and Uzbekistan fell more than two times compared to 1990. In addition, the downstream reservoirs were not able to store the increased releases, and, in order to prevent flooding of the lower reaches of the Syr Darya river, wasteful discharges into the Arnasai depression were required. As early as the vegetation period of 1994, discharges to Arnasai exceeded $8.0 \mathrm{~km}^{3}$, increasing its storage up to $25 \mathrm{~km}^{3}$. 


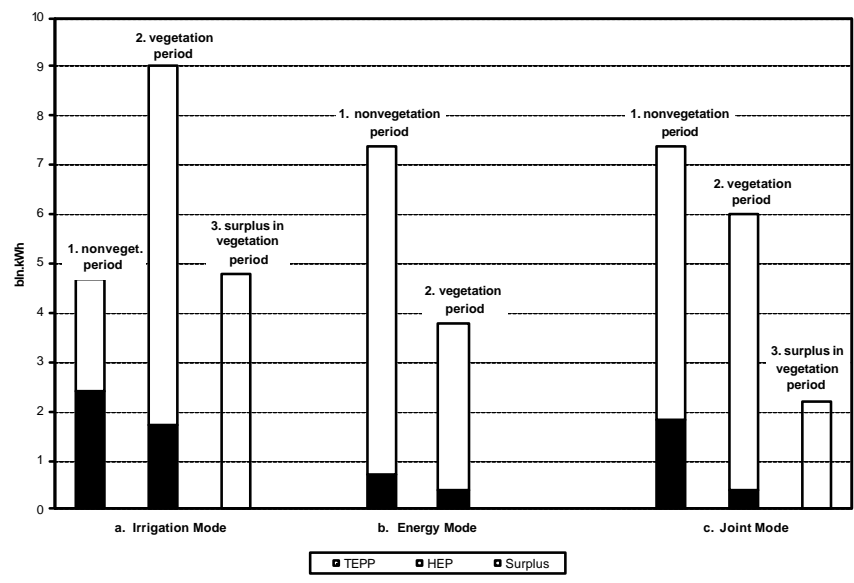

Figure 3. Kyrgyz electricity output under different Toktogul operation scenarios: a - irrigation; $\mathrm{b}$ - energy; $\mathrm{c}$ - joint; 1 - non-vegetation period; 2 - vegetation period; 3 - surplus in vegetation period.

\section{Intergovernmental Relations of Joint Water and Energy Use in the Syr Darya Basin}

In order to overcome increasing difficulties a number of intergovernmental agreements were signed by Kazakhstan, Kyrgyzstan, and Uzbekistan related to the use of water and energy resources in the Syr Darya basin. These agreements specified releases from Toktogul reservoir during vegetation periods to meet basin irrigation demands and non-vegetation period compensative supplies of energy resources (natural gas, electric power, fuel oil, and coal) from Uzbekistan and Kazakhstan to Kyrgyzstan for extra HPP-generated electricity transmitted to those republics due to summer water releases (Figures 2 and $3)$.

Every year, proposals for the mutual supply of water and energy resources are elaborated by working groups from the participating republics at the level of top-management of concerned sectors of the water, fuel, and power industries, and the regional energy and water management bodies (UDC "Energia" and BVO "Syr Darya"). After that, the proposals are ratified in intergovernmental agreements. During the period 1995 to 1998, bi-lateral agreements between Kyrgyzstan and Uzbekistan were signed specifying vegetation period water releases from Toktogul reservoir, typically $6.5 \mathrm{~km}^{3}$ (which has theoretically been split between Uzbekistan and Kazakhstan, but Uzbekistan has first access to the water and Kazakhstan receives high salinity water and sometimes reduced flows) for irrigation purposes in Uzbekistan and Kazakhstan and electric power transfers, typically, 1.1 billion $\mathrm{kWh}$ each to Uzbekistan and Kazakhstan (2.2 billion kWh of electricity received by Kazakhstan, and Uzbekistan is the residual energy remaining from that generated from the $6.5 \mathrm{~km}^{3}$ vegetation period release after Kyrgyz national electric demand is satisfied). Supplies of electric power and coal from Kazakhstan were to be delivered to the Bishkek TPP and electric power, natural gas, and heating oil from
Uzbekistan were to be delivered to Kyrgyzstan. To achieve joint solutions over the near term, heads of the Kazakhstan, Kyrgyzstan, and Uzbekistan governments signed a longterm framework agreement "On the Use of Water and Energy Resources of the Syr Darya Basin" on March 17, 1998. In 1999, the Republic of Tajikistan joined this agreement.

Under the agreements, Kyrgyzstan transmitted to Uzbekistan and Kazakhstan during 1995 to 99, 7,200 million $\mathrm{kWh}$ of surplus electricity due to Toktogul vegetation period releases. During the same period, Kazakhstan and Uzbekistan supplied to the Kyrgyz energy system: 1,500 million $\mathrm{kWh}$ electricity, $1.73 \mathrm{~km}^{3}$ natural gas, 2.17 million tons of coal and fuel oil for the Bishkek TPP autumnwinter operation. Unfortunately, partial alteration of the Toktogul irrigation mode did not solve the problem on the whole.Year-to-year, seasonal redistribution of water for power and irrigation without a comprehensive approach lead to a reduction in Toktogul storage to $7.2 \mathrm{~km}^{3}$ (dead storage totaled $5.5 \mathrm{~km}^{3}$ ) by the beginning of the $1998 \mathrm{veg}$ etation period (Figure 4).

During 1998 and 1999, the terms of the intergovernmental agreements were only partially fulfilled. Favorable hydrologic and weather conditions contributed to reduced vegetation period water demand (Toktogul releases in 1998 totaled $3.7 \mathrm{~km}^{3}$, and in 1999 totaled $5.06 \mathrm{~km}^{3}$ ). Due to this, Kyrgyzstan supplied less electric power to Uzbekistan and Kazakhstan than planned, however, Uzbekistan fulfilled its obligations for natural gas supply. Table 3 summarizes the water releases and the energy resource supplies stipulated by the agreements and actually delivered for the period 1995 to 1999 . By receiving energy resources as compensation for seasonal control of flow through Toktogul reservoir, Kyrgyzstan not only reduces long-term control capability, but sometimes is forced to discharge the longterm stock of the reservoir, thus decreasing the efficiency of flow use and electricity generation at the Naryn Cascade HPPs. Though Kazakhstan and Uzbekistan have been providing some compensation to Kyrgyzstan for extra en-

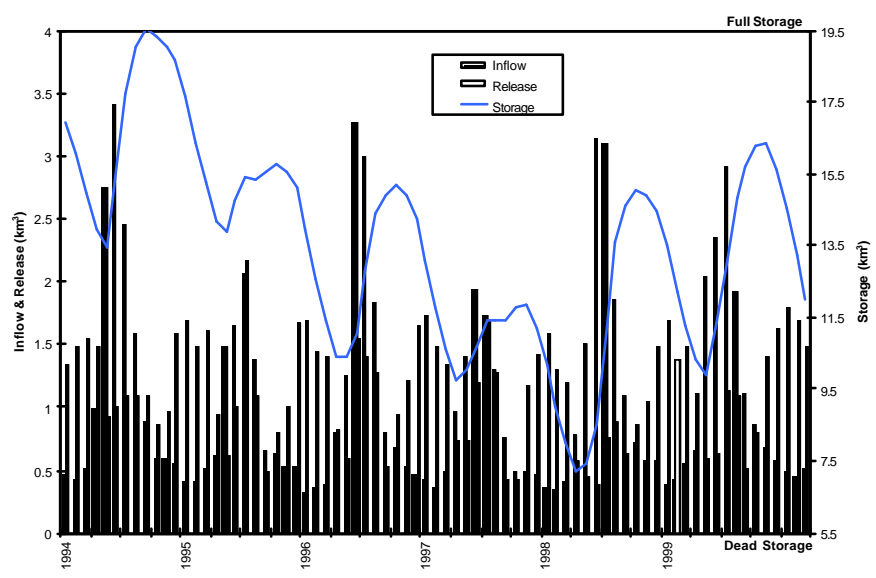

Figure 4. Toktogul reservoir operation 1994 to 1999. 
Table 3. Implementation of Intergrovernmental Agreements on the Use of Water and Energy Resources of the Syr Darya Basin in 1995-1999

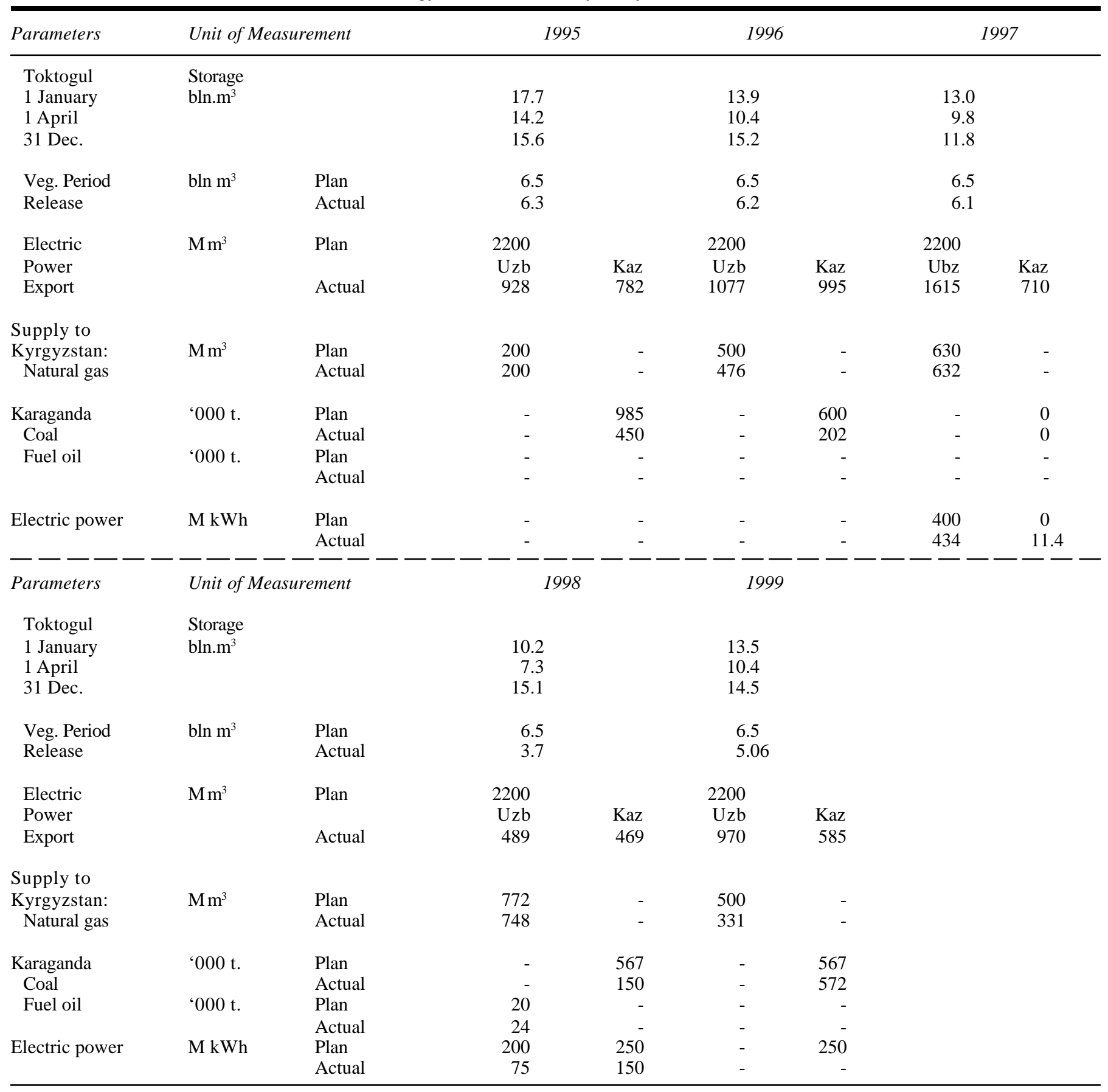

ergy and control of water, these republics, without respective compensation, will not have guarantees of firm water supply on a long-term basis.

In 1999, the governments ratified documents stipulating synchronous or parallel operation of the national energy systems of all Central-Asian republics. These existing agreements (waterandenergy, andparallel qperatiquovile a base for stable regionaboperation in baknced us- • age of waterandfiel-energy resarces. That baseprovides:
- Implementation of coordinated water and energy policy of the republics aimed at joint development and operation of fuel-energy and water resource systems;

- Development of a cooperative program of new structural and regional policy in the development of the water and fuel-energy sectors;

Setting up a common market of energy resources; Elaboration of regulatory legal documents and setting up intergovernmental, market-type structures; and 
- Attraction of investments of private and national capital both from Central Asian republics and other countries.

However, practical implementation of the long-term mechanism of water and energy use requires much additional joint work. This joint work has to be carried out in the engineering, legal, and organizational directions for the purpose of bridging the gap between national legislative acts guiding the relationships of the participants with different forms of ownership.

Due to the fact that the existing pattern of relationships in the water and power sector does not meet the interests of any of the riparian nations of the Syr Darya basin and is not optimal for the region as a whole, the Water and Energy Uses Round Table noted the importance of developing a model to optimize operation modes for the major reservoirs of the Syr Darya basin. The resulting system is a complex of models to assist in solving the tasks of optimal flow control with regard to national and regional benefits and with subsequent agreement on the regimes at the intergovernmental level in order to enter into bilateral and multilateral long-term economic agreements (McKinney and Kenshimov, 2000). In the course of this work, a complex energy model was developed for the Naryn Cascade of HPPs, including the interactions of the Kyrgyz Republic and the other Syr Darya basin countries through water supplies and mutual fuel (energy carrier) deliveries.

\section{Optimization Model of the Naryn Cascade}

\section{Problem Definition and General Requirements of the Model}

The water and energy model described here has been developed using the General Algebraic Modeling System (GAMS) (Brooke et al., 1998; 2001) for the purpose of solving water and energy problems of the Kyrgyz energy system taking into account national benefits and regional water requirements. The model includes two parts: a water part and an energy part. The water part is based on the model of the BVO "Syr Darya" (McKinney and Kenshimov, 2000) and incorporates reservoirs, HPPs, sources, national water users, and water delivery to downstream users. With the help of this program, taking into account the initial data and constraints, flow rates through the HPPs, balances of reservoirs, and water supply to Kyrgyz and downstream users, and the output of HPPS are calculated. The energy part of the model calculates the most efficient load on the generating plants (both thermal and hydro) satisfying Kyrgyz internal energy demand and regional electricity transfers through the CAEP. An economic factor in these calculations is the cost of energy produced and the tariffs for electricity transfers to and from the regional grid. The water and energy parts are interconnected via the output of HPPs. Since the plants of the Naryn Cascade are located on one and the same water course, they are presented in the energy part as a single plant with the total output of all plants of the cascade.

\section{Initial Data}

The model has been developed for the Kyrgyz energy system. Diagrams of the water and energy parts of the model are shown in Figure 5. The time step used in the model is one month. The water part includes the following:

- Five water reservoirs of the Naryn Cascade: Toktogul, Kurpsai, Tashkumyr, Shamaldysai, and Uch-Kurgan;

- Three water sources: inflow to Toktogul reservoir, and lateral inflows to both Kurpsai and Tashkumyr reservoirs;

- Two Kyrgyz water users: water diversions from UchKurgan reservoir to the Left Bank Canal (LBC) and Big Namangan Canal (BNC); and

- River mouth transmission of water to downstream water users from the Uch-Kurgan HPP: Uzbekistan, Tajikistan, Kazakhstan, and the Aral Sea.

The energy part of the model includes the following:

- Generating plants (HPP and TPP) whose loads are calculated by the model taking into account costs and imposed constraints;

- Off-design plants whose loads are specified and remain unchanged in all calculations;

- A single energy consumer, the internal demand of the Kyrgyz Republic; and

- Regional energy transfer to and from the CAEP.

The entities and initial information included in the model are listed in Tables 4 through 9.

\section{Optimization Criteria}

The optimization criterion in this model is to minimize the cost of providing the Kyrgyz Republic's internal energy demand while taking into account Toktogul reservoir operation in the electricity generation or irrigation modes. This criterion is embodied in the objective function as minimization of electricity production costs for thermal and hydroelectric plants and the squared differences between modeled energy delivery and demand

Minimize $\sum_{t}\left\lfloor C_{H} E H_{t}+C_{G} E G_{t}+C_{O} E O_{t}+\left(E_{K y r g y z, t}-E D_{K y r g y z}, t\right)^{2}\right\rfloor$

where $C_{H}$ is the electricity production cost for TPP (\$/ million $\mathrm{kWh}$ ); $C_{G}$ is the electricity production cost for Naryn Cascade HPP (\$/million $\mathrm{kWh}) ; C_{O}$ is the cost for electricity transfer to/from CAEP (\$/million $\mathrm{kWh}) ; E H_{t}$ 


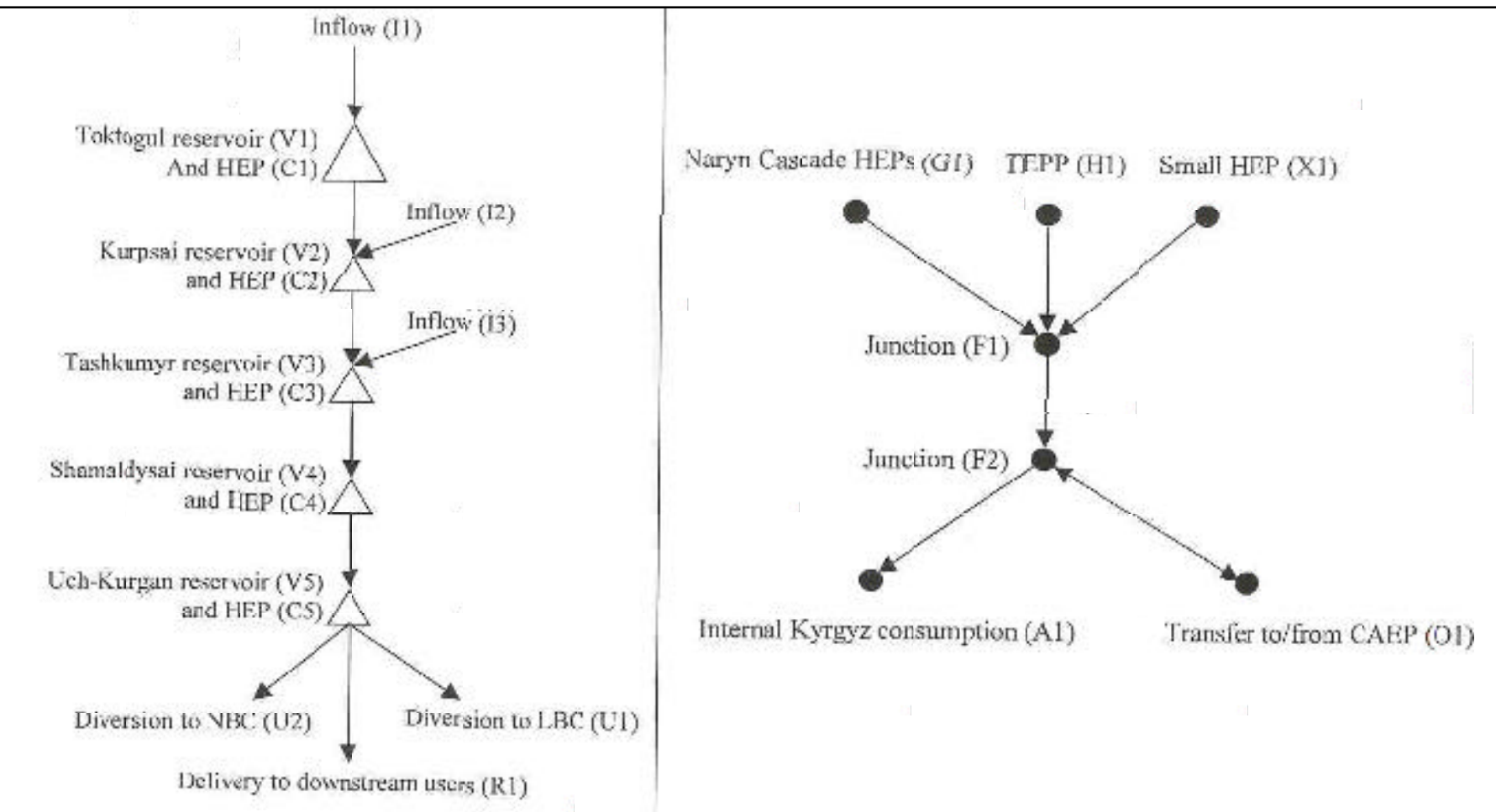

(a) Water part - Diagram of Naryn Cascade HPPs

(b) Energy part - Diagram of Kyrgyz energy system

Figure 5. Diagram of the Naryn Cascade HPPs.

Table 4. Initial Model Data

Item (see Figures 4 and 5)

Inflows $(I)$

Reservoirs $(V)$

HPP $(C)$ in the water part of the model

HPPs $(G)$ in the energy part of the model.

$\operatorname{TPP}(H)$

Small HPP $(X)$

Electric power consumers $(A)$

Export-import of electric power from

Water users $(U)$

River mouth $(R)$
Initial Information

- Values of average long-period inflow for every time interval for every source.

- Curves of reservoir storage capacities as a function of water levels

- Constraints (maximum and minimum) on each reservoir storage

- Reservoir storage at the beginning of calculation.

- For Toktogul reservoir, total water discharge for a given period of time (year or vegetation season) can be set.

- Constraints on the flow rates through turbine units.

- Downstream water elevation as a function of flow rate through HPPs.

- Hydropower unit efficiencies with regard for losses in the penstock, turbine and generator.

- Cost of electric power.

- Constraints on output for a time interval (maximum and minimum).

- Cost of electric power.

- Average output of small HPPs for a time interval.

- Internal demand of the Kyrgyz Republic for a time interval.

- Transfers of electric power can be both set and estimated values.

- Tariffs for electric power CAEP $(O)$ transfers.

- Water demand for every time interval for every user.

- When solving the problems of water flow control, constraints on water releases can be set both for a given time interval, and a specified period (year, vegetation season). 
Table 5. Average Long-term Inflows

\begin{tabular}{|c|c|c|c|c|c|c|c|c|c|c|c|c|c|}
\hline Item & Units & Oct. & Nov. & Dec. & Jan. & Feb. & Mar. & Apr. & May & Jun. & Jul. & Aug. & Sep. \\
\hline $\begin{array}{l}\overline{\text { Inflow to }} \\
\text { Toktogul } \\
\text { reservoir }\end{array}$ & $\mathrm{Mm}^{3}$ & 557.1 & 471.7 & 380.3 & 372.3 & 331.4 & 420.5 & 5962 & 14463 & 2255.0 & 2.2499 & 1392.8 & 777.6 \\
\hline $\begin{array}{l}\text { Lateral inflow } \\
\text { to Kurpsai } \\
\text { reservoir }\end{array}$ & $\mathrm{M} \mathrm{m}^{3}$ & 26.8 & 23.3 & 21.4 & 30.8 & 28.8 & 32.1 & 33.2 & 64.3 & 88.1 & 133.9 & 93.7 & 33.7 \\
\hline $\begin{array}{l}\text { Lateral inflow } \\
\text { to Tashkumyr } \\
\text { reservoir }\end{array}$ & $\mathrm{M} \mathrm{m}^{3}$ & 107.1 & 101.1 & 88.4 & 62.9 & 58.9 & 88.4 & 267.5 & 372.3 & 303.3 & 155.3 & 136.6 & 124.4 \\
\hline $\begin{array}{l}\overline{\text { Diversion to }} \\
\text { left-bank canal } \\
\text { (LBC) }\end{array}$ & $\mathrm{Mm}^{3}$ & 13.4 & 13.0 & 13.4 & 13.4 & 12.1 & 13.4 & 38.9 & 40.2 & 38.9 & 40.2 & 40.2 & 38.9 \\
\hline $\begin{array}{l}\text { Diversion to } \\
\text { Big Namangan } \\
\text { Canal (BNC) }\end{array}$ & $\mathrm{Mm}^{3}$ & 40.2 & 25.9 & 26.8 & 26.8 & 24.2 & 40.2 & 64.8 & 80.4 & 77.8 & 107.1 & 107.1 & 51.8 \\
\hline $\begin{array}{l}\overline{\text { nternal K}} \overline{\text { yrgyz }} \\
\text { demand }\end{array}$ & $\mathrm{MkWh}$ & 746 & 1,121 & 1,520 & 1,666 & 1,394 & 1,366 & 917 & 635 & 535 & 550 & 547 & 532 \\
\hline
\end{tabular}

is the electricity production of TPP in period $t$ (million $\mathrm{kWh}$ ); $E G_{t}$ is the electricity production of Naryn Cascade HPP in period $t$ (million $\mathrm{kWh}) ; E O_{t}$ is the electricity transfer to/from CAEP in period $t$ (million $\mathrm{kWh);} E_{K y r g y z, t}$ is the energy produced for Kyrgyz Republic in period $t$ (million $\mathrm{kWh}$ ); and $E D_{\text {Kyrgyz,t }}$ is theKyrgyz Republic's internal energy demand in period $t$ (million $\mathrm{kWh}$ ).

For water users, the optimization criterion is similar to that in the BVO "Syr Darya" model (McKinney and Kenshimov, 2000). The main criterion is to minimize deficits of water delivery to all users

$$
\text { Minimize } \sum_{t} \sum_{j=1}^{3} \frac{W_{r e q, j, t}-W_{i n, j, t}}{W_{r e q, j, t}}
$$

where $W_{r e q, j, t}$ is the demand for $\operatorname{LBC}(j=1), \operatorname{BNC}(j=$ $2)$, and downstream users $(j=3)\left(\mathrm{m}^{3}\right)$; and $W_{i n, j, t}$ is the delivery to $\operatorname{LBC}(j=1), \operatorname{BNC}(j=2)$, and downstream users $(j=3)\left(\mathrm{m}^{3}\right)$.

\section{Constraints}

The water part of the model is a sequential arrangement of the five reservoirs and HPPs of the Naryn cascade with lateral inflows and water diversions. For every reservoir, water storage balances are observed as follows:

$$
V_{j, t}-V_{j, t-1}=\sum_{i n} W_{i n, j, t}-W_{o u t, j, t}
$$

where $V_{j, t}$ is the volume of water in reservoir $j$ at time $t$ $\left(\mathrm{m}^{3}\right) ; W_{\text {out }, j, t}$ is the release from reservoir $j$ in period $t$ $\left(\mathrm{m}^{3}\right)$; and $W_{i n, j, t}$ is the inflow to reservoir $i$ in period $t$ $\left(\mathrm{m}^{3}\right)$;

The generation of each HPP of the Naryn Cascade is calculated according to the following equation:

$$
P_{j, t}=\gamma * \varepsilon_{j} * Q_{j, t} * \Delta H_{j, t}
$$

where $P_{j, t}$ is the power generated by HPP $j$ in period time $t(\mathrm{~kW}) ; Q_{j, t}$ is the flow through HPP $j$ in period time $t\left(\mathrm{~m}^{3} / \mathrm{sec}\right) ; \Delta H_{j, t}$ is the effective head on HPP $j$ in period time $t(\mathrm{~m})$; and $\varepsilon_{j}$ is the efficiency of HPP $j$. The output of electric energy at HPPs for the design period is calculated according the following equation:

$$
E_{j, t}=\Delta t / 3600 * P_{j, t}
$$

where $E_{j, t}$ is the energy generated by HPP $j$ in period time $t$ (million $\mathrm{kWh}$ ); and $\Delta t$ is the number of seconds in the period $t$.

All entities of the energy part of the model are connected by one equation: the total output of all generating plants is equal to the internal consumption and balance of transfers to/from the CAEP

$$
\sum_{t}\left[E H_{t}+E G_{t}+E S G_{t}\right]=\sum_{t}\left(E_{K y r g y z, t}+E O_{t}\right)
$$


where $E S G_{t}$ is the power output of the non-calculated power stations. The relationship of the water part and the energy part of the model is

$$
\sum_{j \in G} E_{j, t}=E G_{t}
$$

In order to provide for compulsory minimum loading of the Kyrgyz TPPs (according to the heating schedule), constraints (simple upper bounds) on the electric power output of Kyrgyz plants are introduced. These constraints can be changed depending on the availability of fuel (coal and gas) in the Kyrgyz Republic.

\section{Results}

\section{Model Verification}

To verify the reliability of the model, the 1998 to 1999 operation mode of Toktogul reservoir was modeled. The initial information used was the actual energy balance of Kyrgyzenergo from October 1998 to October 1999, as well as actual water levels of reservoirs and reservoir inflow. The results gave the operation mode of the reservoirs and electric power output for each Naryn Cascade HPP. The difference between the modeled and actual volumes of water released from Toktogul was 270 million $\mathrm{m}^{3}$, or 2.9 percent of the actual value. In addition, analysis of the output of each HPP was performed. The results suggest that on the Shamaldysai-Uch-Kurgan section there are unaccounted for water losses because the modeled output exceeds the actual. The other reaches show an opposite trend: this imbalance may be connected with inaccurate estimation of lateral inflows on these reaches.
For additional details on the verification of the model see Zyryanov and Antipova (2000).

\section{Three Scenarios of Operation of the Naryn Cascade}

Three operation scenarios of the Naryn Cascade HPPs and the energy system of Kyrgyzstan were modeled. Table 8 shows the results of modeling each scenario. Toktogul reservoir storage volumes are shown in Figure 6 for all three scenarios.

Scenario 1 considers the problem of electric power supply to internal consumers of Kyrgyzstan with no electricity transfer through the CAEP. The results show that the electric power output of the Kyrgyz TPPs was 847 million $\mathrm{kWh}$, complying with the heating schedule. The output of the Naryn Cascade HPPs was 10,500 million $\mathrm{kWh}$ and the annual release of water through the hydropower units of the Toktogul HPP was $11.6 \mathrm{~km}^{3}$, exceeding the annual long-term inflow of Toktogul reservoir.

Scenario 2 envisages operation of Toktogul reservoir according to the irrigation regime in the vegetation period. This scenario models the intergovernmental agreements of 1995 to 1999. In this case, additional constraints were introduced:

- Minimum volume of water released through the Toktogul HPP in the vegetation period $\left(6.5 \mathrm{~km}^{3}\right)$; and

- On electricity transfers to/from the CAEP: No electric power transfer in the non-vegetation period, and positive electric power transfers in the vegetation period to allow for electric power output above the Kyrgyz internal demand due to irrigation water releases.

The results show that surplus electric power of 2,710

Table 6. Average Monthly Power Generation.

\begin{tabular}{|c|c|c|c|c|c|c|c|c|c|c|c|c|c|c|}
\hline \multirow[t]{2}{*}{ TPP } & $\max$ & M kWh & 345 & 345 & 345 & 345 & 345 & 345 & 100 & 45 & 45 & 45 & 45 & 45 \\
\hline & $\min$ & $\mathrm{M} \mathrm{kWh}$ & 60 & 125 & 125 & 130 & 130 & 125 & 60 & 15 & 15 & 15 & 15 & 15 \\
\hline HPP & actual & $\mathrm{M} \mathrm{kWh}$ & 16 & 18 & 19 & 16 & 15 & 19 & 16 & 21 & 20 & 25 & 25 & 20 \\
\hline HPP & $\max$ & M kWh & 2,135 & 2,066 & 2,135 & 2,135 & 1,929 & 2,135 & 2,066 & 2,135 & 2,066 & 2,135 & 2,135 & 2,066 \\
\hline
\end{tabular}

Table 7. Costs of Electric Power from Power Plants and Transfer from CAEP

\begin{tabular}{llllll}
\hline \multicolumn{4}{c}{ Type of Power Plant } \\
& TPP & HPP & $\begin{array}{l}\text { Small } \\
\text { HPP }\end{array}$ & Transfer from CAEP \\
\hline $\begin{array}{l}\text { Cost } \\
\text { (tin/kWh) }\end{array}$ & 922 & 1.3 & 3.7 & Rate $($ tin $/ \mathrm{kWh})$ & 100 \\
\hline
\end{tabular}

million $\mathrm{kWh}$ was generated (Table 8 ). In this case Toktogul operates as a seasonal regulator of releases for irrigation in the Syr Darya basin of $6.5 \mathrm{~km}^{3}$. In the non-vegetation period (since no fuel deliveries from downstream countries are assumed) to provide for Kyrgyz internal electrical consumption, release of $9.0 \mathrm{~km}^{3}$ water is required through the Toktogul HPP. The annual output of the Naryn Cascade HPP was 13,000 million $\mathrm{kWh}$ and of the TPPs, 1,050 million $\mathrm{kWh}$. 


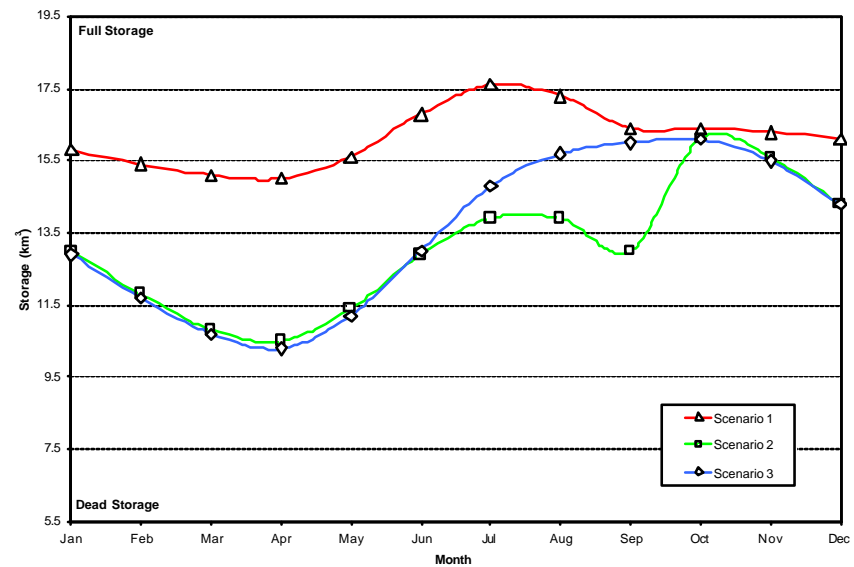

Figure 6. Toktogul reservoir operation under three scenarios.

According to Scenarios 1 and 2, thermal power generation remains at a minimum level equal to 1875 thousand Gcal $(1 \mathrm{Gcal}=1$ billion calories $=1,163 \mathrm{kWh}$. So, $1,875,000 \mathrm{Gcal}=2,181$ million $\mathrm{kWh}$ ). in the non-vegetation (October to March) period. Therefore, the Kyrgyz internal electrical demand, according to these scenarios, is much higher because the population must use electric resistance heating appliances. This requires raising the output of the Naryn Cascade HPPs and increasing releases from Toktogul. This result (annual water release from Toktogul of $15.5 \mathrm{~km}^{3}$ along with the annual long-term inflow of $11.2 \mathrm{~km}^{3}$ ) would cause severe drawdown of the Toktogul reservoir and therefore rather serious problems both in the energy sector of Kyrgyzstan and in the whole integrated water system of the Syr Darya basin.

Scenario 3 considers the problem of long-term control of the Naryn river. The only constraints are on the annual release of water from Toktogul equal to the annual longterm inflow of the Naryn river to the Toktogul Hydrosystem. The results show that TPP electric power output is 2,400 million $\mathrm{kWh}$ with maximum generation in the non-vegetation period, resulting in minimal Kyrgyz hydropower demand in this period. The output of the Naryn Cascade HPPs is 10,500 million $\mathrm{kWh}$, and electricity import from the CAEP in the non-vegetation period is 2,100 million $\mathrm{kWh}$. Electricity export to the CAEP in the vegetation period is 3,700 million $\mathrm{kWh}$, and the annual release from Toktogul is $11.2 \mathrm{~km}^{3}$, including $7.4 \mathrm{~km}^{3}$ in the vegetation period. Finally, to meet the Kyrgyz heating demand of 2.6 thousand Gcal, the gross annual output of the Kyrgyz TPPs is 6,600 million $\mathrm{kWh}$.

Table 8. Results of Three Scenarios of Operation of the Naryn Cascade

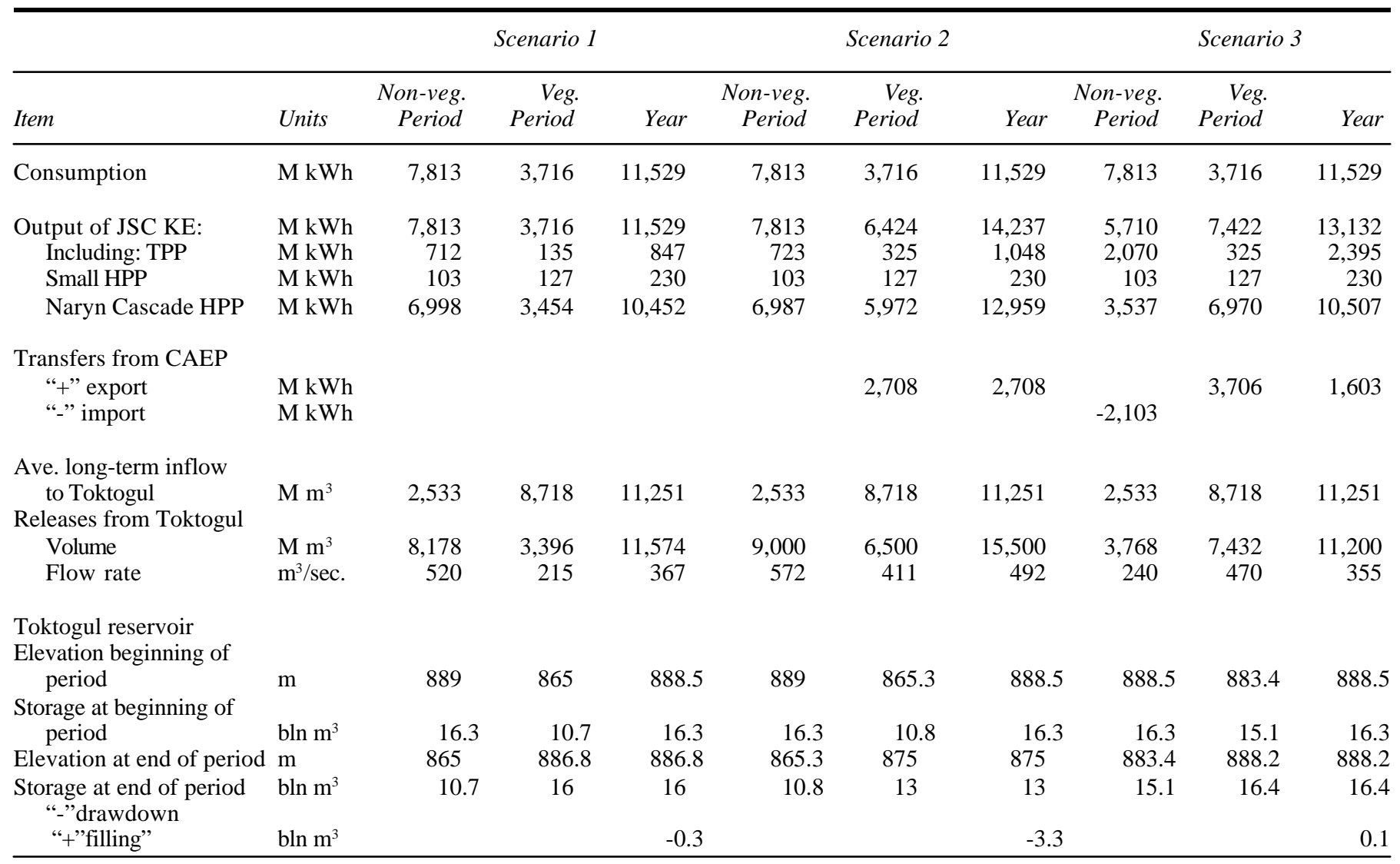




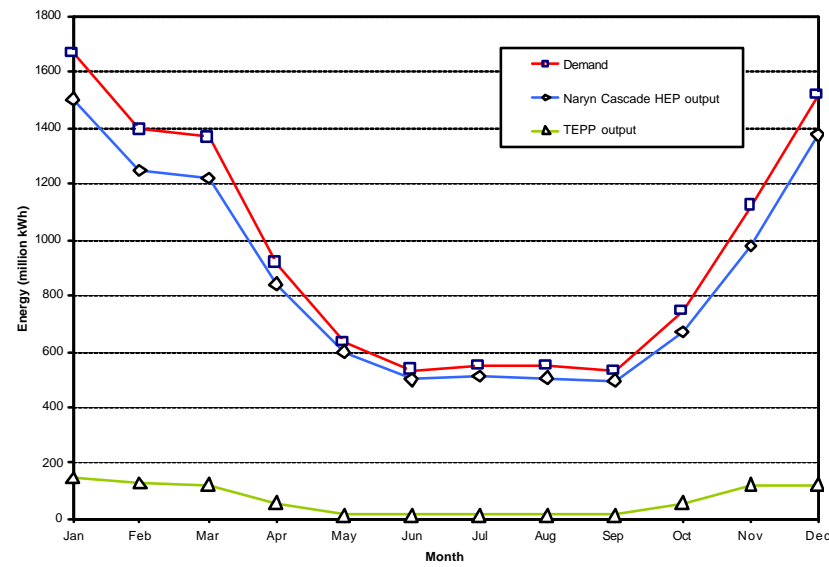

Figure 7. Kyrgyz energy balance under Scenario 1.

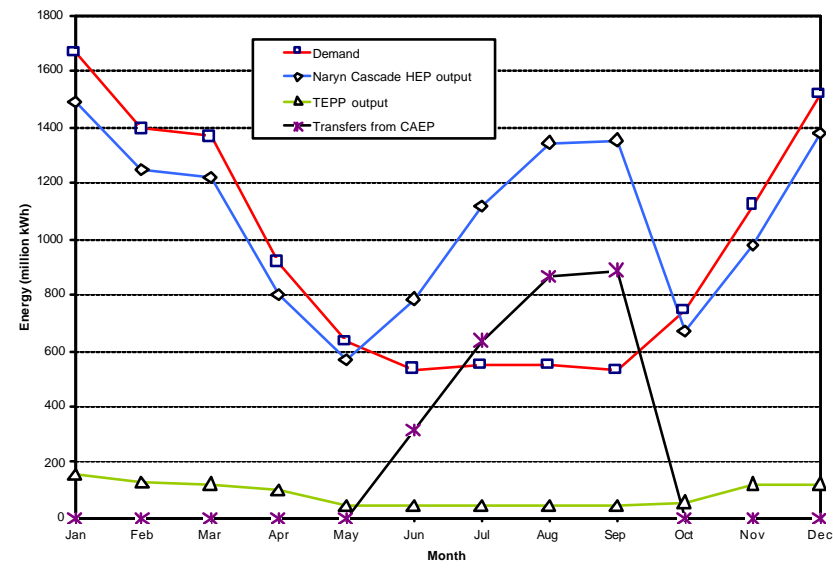

Figure 8. Kyrgyz energy balance under Scenario 2 (transfer from CAEP "+" = export; "-" = import.

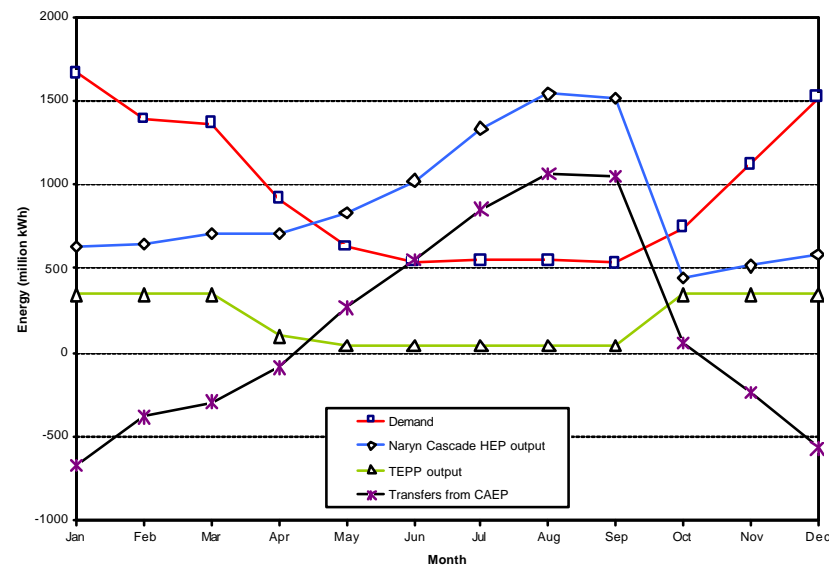

Figure 9. Kyrgyz energy balance under Scenario 3 (transfer from CAEP “+" = export; "-" = import.

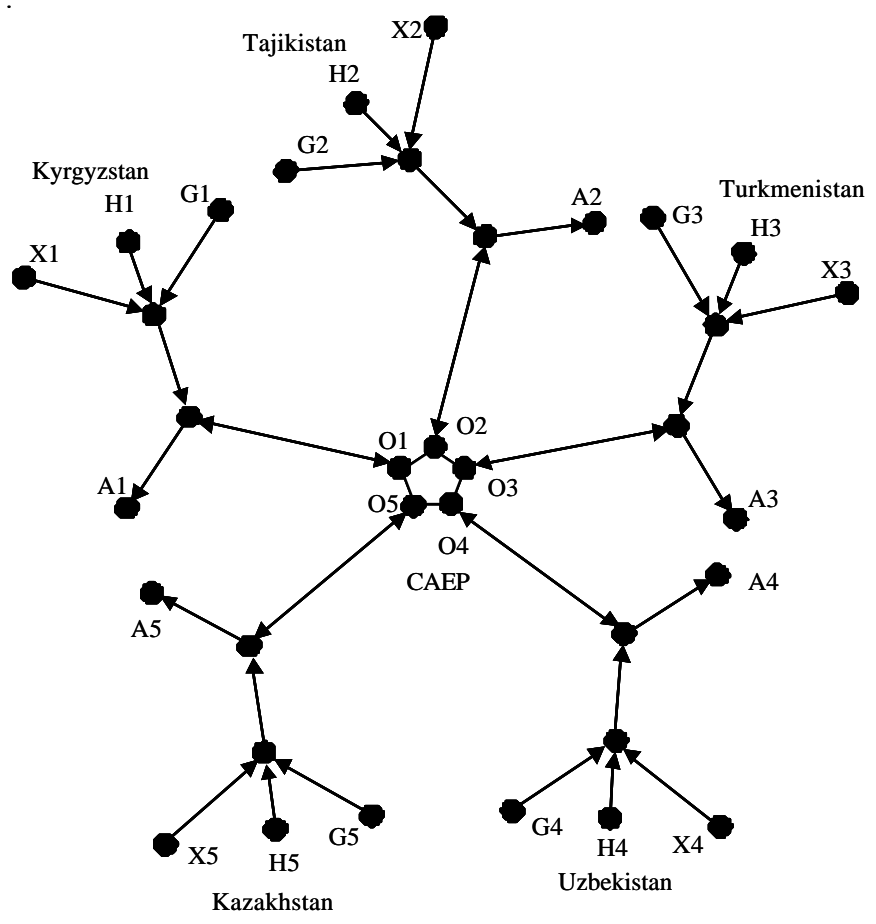

Figure 10. Diagram of the energy part of the Central Asian Water and Energy model.

\section{Conclusions}

The recent experience of cooperation in the use of the Syr Darya basin water and energy resources on the basis of intergovernmental agreements has been seasonal. It considers primarily the benefits of energy resource exchanges and does not solve the task of long-term, balanced use of water. This can cause, as was seen recently, the early depletion of Toktogul reservoir storage and huge losses both in the power and water sectors of the Central Asian republics. A situation similar to the depletion of all active storage in Toktogul reservoir arose in the beginning of the vegetation period of 1998 , following the low-water year of 1997.

Apart from this, in the non-vegetation periods of 1999 to 2000 and 2000 to 2001, the supply of natural gas to Kyrgyz TPPs was terminated by Uzbekistan. As a result, because of extra loading of the Naryn Cascade HPPs, the release of water from Toktogul was increased substantially in those periods compared to the same period of earlier years. Much of the additional discharge of water was required to be thrown into the Arnasai depression from the Chardara reservoir and this aggravated the ecological situation in the lower reaches of the basin. These factors confirm the necessity of the parties fulfilling the annual intergovernmental obligations and the need for multi-year operation procedures for long-term control and use of water from Toktogul.

Within the framework of the model presented here, calculations of operating Toktogul with different sets of 
initial parameters have been performed. The results confirm that it is possible to change the regime of releases from Toktogul provided that the parties increase compensating supplies of energy resources. The results of the model can be used by the parties for further work on interrelations of all basin components and elaboration of a model of long-term control and usage of water and energy resources in the Syr Darya basin. There are several outstanding issues in the implementation of the 1998 Syr Darya agreement, including the need to have longer-term analyses to remove the effects of hydrologic fluctuations on compensation. The model presented here can be used to analyze these questions and assist in the development of new proposals. This model has been fully integrated into the previously developed "BVO Syr Darya" model and can be solved for the detailed water delivery in the basin as well as consideration of salt concentrations in the river.

The interaction between the water and energy sector for Kyrgyzstan that is implemented in the model described above is limited in scope to one country's energy sector. However, the water-energy interactions in Central Asia, and especially in the Syr Darya basin, are much more complex than that and often involve all five republics. The model described here has been extended to a comprehensive model of water and energy use in the Aral Sea basin, including both the Syr Darya and Amu Darya river basins and the energy systems of all five Central Asian republics (Figure 10).

\section{Acknowledgements}

Financial support for this work was provided by the United States Agency for International Development (USAID) under contract Contract No. PCE-I-00-9600002-00, Task Order No. 813, Environmental Policies and Institutions for Central Asia implemented by International Resources Group. Ltd. The opinions expressed here are those of the authors and imply no position or opinion of the US government or USAID.

\section{About the Authors}

Elena Antipova is a Hydropower Engineer at the Hydrotechnical Service, Joint Stock Company Kyrgyzenergo, Bishek, Kyrgyz Republic.
Alexi Zyryanov is Head of the Hydrotechnical Service, JSC Kyrgyzenergo, Bishek, Kyrgyz Republic.

Daene McKinney is an Association Professor in the Environmental and Water Resources Engineering Program, The University of Texas at Austin, Austin, Texas. From 1998 to 2000, he was Chief of Party for the US Agency for International Development Environmental Policies and Institutions for Central Asia (EPIC) Program. Email: Daene@aol.com.

Andre Savitsky, Hydrologist, Ecological Center, Tashkent, Uzbekistan.

Discussions open until June 1, 2003.

\section{References}

Brooke A., D. Kendrick, and A. Meeraus. 1998. GAMS: A User's Guide. Washington, D.C., USA: GAMS Development Corporation.

McKinney, D.C. and A.K. Kenshimov, eds. 2000. Optimization of the Use of Water and Energy Resources in the Syr Darya Basin Under Current Conditions, Technical Report 00-06W. Almaty, Kazakhstan: Environmental Policies and Institutions for Central Asia (EPIC) Program, US Agency for International Development. http://www.ce.utexas.edu/ prof/ mckinney/papers/aral/00-06-W/EPIC-00-06-W.htm.

McKinney, D.C. and A.G. Savitsky. 2001. GAMS Tutorial for Water and Energy Management, Technical Report 99-13-W. Almaty, Kazakhstan: Environmental Policies and Institutions for Central Asia (EPIC) Program, US Agency for International Development.

Zyryanov, A. and E. Antipova. 2000. "Optimization of the Syr Darya Water and Energy Uses under Current Conditions." D.C. McKinney and A.K. Kenshimov, eds. Optimization of the Use of Water and Energy Resources in the Syr Darya Basin Under Current Conditions, Technical Report 00-06W, Vol. 2, Section 2.1. Almaty, Kazakhstan: Environmental Policies and Institutions for Central Asia (EPIC) Program, US Agency for International Development. 